\begin{tabular}{l} 
Jurnal Pakarena \\
Volume 4 Nomor 2 Desember 2019 \\
e-ISSN: 2714-6081 dan p-ISSN: $2528-6994$ \\
\begin{tabular}{|l|l|} 
(c) T) This work is licensed under a Creative Commons Attribution \\
PAKARENA
\end{tabular} \\
\hline
\end{tabular}

\title{
Tari Pa'randing Di Tana Toraja: Kajian Struktur Gerak
}

${ }^{1}$ Feranita, ${ }^{2}$ Sumiani, ${ }^{3}$ Rahma M.

\author{
Keywords : \\ Struktur; \\ Gerak Tari; \\ Pa'randing; \\ Tana Toraja
}

\section{Corespondensi Author} Prodi Seni Tari, FSD UNM

Jl. Malengkeri Kampus UNM

Email: fhernita42@gmail.com

\begin{abstract}
ABSTRAK
Struktur Gerak Tari Pa'randing di Tana Toraja, skripsi, Fakultas Seni dan Desain Universitas Negeri Makassar. Penelitian ini bertujuan memperoleh data dan informasi tentang: 1) deskripsi gerak tari Pa'randing dengan Notasi Laban, 2) deskripsi tata hubungan ragam gerak tari Pa'randing di Tana Toraja. Penelitian ini adalah penelitian kualitatif dengan metode deskriptif yang akan menggambarkan keadaan berdasarkan hasil penelitian di lapangan. Pengumpulan data dilakukan dengan observasi, wawancara dengan informan masyarakat Toraja yang dianggap mengetahui tari Pa'randing secara mendalam dan dokumentasi. Hasil penelitian ini menunjukkan bahwa: 1) Tari Pa'randing mempunyai tiga ragam gerak yaitu ragam gerak biasa atau Pamula, ragam gerak Tekka Tallu dan ragam gerak Ma'putara yang menjelaskan gerakanya dalam struktur yang merupakan sebuah sistem atau lambang (tanda), artinya gabungan atau rangkaian dari beberapa elemen-elemen yang dirakit sedemikian rupa hingga menjadi satu kesatuan yang utuh dalam bentuk Notasi laban yang dilihat dari bentuk tangan, kaki, dan badan yang digambarkan dalam Notasi laban. 2) Tata hubungan dalam tari ini termasuk tata hubungan bentuk Marfologis yang saling berhubungan antara ragam gerak.
\end{abstract}
ABSTRACT
Feranita, 2018, Structure of the Pa'randing Dance in Tana Toraja, thesis, Faculty of Art and Design, Makassar State University. This study aims to obtain data and information about: 1) a description of the motion of Pa'randing dance with Laban Notation, 2) a description of the relationship of the variety of movements of Pa'randing dance in Tana Toraja. This research is a qualitative research with descriptive method that will describe the situation based on the results of research in the field. Data collection was carried out by observation, interviews with informants from the Toraja community who were considered to know the $P a$ randing dance in depth and documentation. The results of this study indicate that: 1) Pa'randing dance has three motions, namely ordinary or Pamula motions, Tekka Tallu motions and Ma'putara motions that describe their movements in structures that are a system or symbol (sign), 
Jurnal Pakarena, Vol. 4 No. 2 Desember 2019, hlm 62-71

meaning a combination or a series of several elements that are assembled in such a way as to become a unified whole in the form of Laban notation which is seen from the shape of the hands, feet, and body described in Laban Notation. 2) Arrangement of relations in this dance including the arrangement of marphological forms that are interconnected between the various movements. .

\section{PENDAHULUAN}

Tari sebagai salah satu cabang kesenian yang merupakan ekspresi manusia yang paling mendasar dan paling tua. Manusia dengan tubuhnya merasakan ketegangan dan ritme alam sekitarnya, kemudian mengekspresikan responsrespons perasaannya kepada alam sekitarnya. Manusia melalui struktur persepsi dan perasaan menciptakan tari, dan melalui tari manusia dapat berhubungan dengan sesamanya dan dunianya, banyak tari tradisional dan kreasi baru dengan memiliki bentuk tari yang berbeda-beda dan biasanya mempunyai makna masing-masing dengan filosifi masyarakatnya (M. Jazuli, 2016: 33).

Sebuah ujud tari selalu memiliki struktur yang antara tarian satu dengan lainnya berbeda. Struktur tari merupakan hasil olahan dari elemen gerak, ruang dan waktu yang berupa bentuk dan gaya tari (M. Jazuli, 2016: 37). Struktur tari adalah susunan gerak yang saling berhubungan yang tersusun menjadi satu. Di Sulawesi Selatan terdapat banyak kesenian tari Tradisional yang bentuk tari yang mengandung nilai-nilai luhur yang dibentuk dalam pola-pola gerak tertentu dan telah berkembang nilai-nilai filosofis yang dalam, simbolis, religius dan tradisi yang tetap salah satunya Suku Toraja.

Suku Toraja adalah salah satu dari ribuan suku di Indonesia yang kaya akan budaya yang penuh dengan keunikan tingkah manusia yang merupakan warisan dari leluhur. Keunikan dan keaslian inilah yang membuat Toraja terkenal sampai ke luar negeri dan menjadi salah satu budaya warisan dunia. Salah satu upacara adat yang masih sering dilakukan di Toraja adalah Upacara Rambu Solo' yang merupakan acara yang berhubungan dengan kematian dan kedukaan (Akin Duli dan Hasanuddin, 2003: 28). Dalam prosesi Upacara Rambu Solo' terdapat banyak tahapan ritual unik dan sangat menarik bagi masyarakat Toraja. Tahapan-tahapan pelaksanaan Upacara Rambu Solo' merupakan suatu peristiwa yang mengandung dimensi religi dan sosial (Robi Panggarra, 2015: 8).

Rambu Solo' merupakan Upacara pemakaman orang yang sudah meninggal. Sebuah tempat prosesi pemakaman disebut Rante biasanya disiapkan pada sebuah padang rumput yang luas, selain sebagai tempat pelayat yang hadir, juga sebagai tempat lumbung padi, dan berbagai perangkat pemakaman lainnya yang dibuat oleh keluarga yang ditinggalkan. Musik, suling, nyanyian, lagu dan puisi, tangisan dan ratapan merupakan ekspresi dukacita yang dilakukan oleh suku Toraja. Mereka menari untuk menunjukkan rasa dukacita, dan untuk menghormati sekaligus menyemangati arwah almarhum karena sang arwah akan menjalani perjalanan panjang menuju akhirat (Nolvianti, 2013: 4).

Salah satu Tari yang dipentaskan dalam Upacara Rambu Solo' adalah tari $P a$ 'randing kata randing yang berarti untuk memuliakan keberanian orang yang meninggal ketika masih hidup dan menghormati tamu dengan tarian. Tari ini merupakan tarian yang melambangkan kepahlawanan atau tari perang yang dibawakan oleh laki-laki dan ditampilkan sebagai demonstrasi untuk mempertunjukan kedewasaan fisik. Laki- 
laki mendemonstrasikan kemampuannya dalam menggunakan senjata seperti pedang, perisai dari kulit kerbau, tanduk kerbau, dan giring-giring. Tarian $P a$ 'randing mengawali prosesi ketika jenazah di bawa dari lumbung padi menuju Rante, tempat upacara pemakaman. Tarian ini awalnya ditampilkan jika terjadi sebuah perang untuk melawan serangan desa luar, tapi sekarang ditampilkan pada upacara pemakaman seorang bangsawan yang dalam acara tersebut dikorbankan dua puluh empat kerbau atau lebih dari dua puluh empat kerbau.

Bila ditinjau lebih dalam Struktur gerak tari Pa'randing tersusun dalam keterkaitan tata hubungan unik yang membangun satu kesatuan bentuk karena struktur memandang tari dari pendekatan bentuk. Tari Pa'randing rupanya sangat menarik untuk di teliti terlihat dari hitungan geraknya hanya sampai 7 hitungan maka penulis terdorong untuk meneliti Struktur gerak tari Pa'randing di Tana Toraja dengan melihat dari geraknya terstruktur yang memiliki ciri khas yang membedakan dengan tarian lain yang hitungannya hanya sampai 7 hitungan dan susunan ragam geraknya dengan mengulang-ulang gerak dari ragam gerak Pamula ke ragam Tekka Tallu dan ragam Ma'putara dan kembali lagi ke ragam kedua.

Berdasarkan hal di atas peneliti tertarik untuk meneliti struktur gerak tari $P a$ 'randing di Tana Toraja karena tari ini memiliki karakter gerak yang unik dengan dominan langkah kaki yang seakan-akan melakukan peperangan dengan hitungan geraknya hanya sampai tujuh hitungan dan ragam geraknya tertata dan saling berhubungan maka penulis merasa tertarik untuk mengkaji struktur gerak tari Pa'randing di Tana Toraja dengan menguraikan gerak kedalam bentuk penulisan Notasi Laban untuk menyajikan tiap detail gerak melalui simbol-simbol dalam notasi laban dan kemudian dideskripsikan. Maka dari itu peneliti tertarik untuk mempelajari lebih dalam mengenai Struktur Gerak Tari Pa'randing di Tana Toraja.

Berdasarkan latar belakang diuraikan di atas, maka di rumuskan sebagai berikut:

1. Bagaimana uraian gerak tari Pa'randing dengan Notasi Laban?

2. Bagaimana tata hubungan ragam gerak tari $\mathrm{Pa}$ 'randing di Tana Toraja?

\section{METODE PENELITIAN \\ Variabel dan desain penelitian}

1. Variabel penelitian

Ada dua variabel yang dikaji dala penelitian ini yaitu:

a. Bagaimana uraian gerak tari $P a$ 'randing dengan Notasi Laban?

b. Bagaimana tata hubungan ragam gerak tari Pa'randing di Tana Toraja?

2. Desain penelitian

a. Pengumpulan data

b. Pengelolahan data dan analisis data

c. Kesimpulan

\section{Teknik Pengumpulan Data}

Sesuai dengan tujuan penelitian ini, maka data yang dikumpulkan adalah data informasi mengenai uraian gerak tari Pa'randing di Tana Toraja dan tata hubungan ragam gerak tari $P \mathrm{~Pa}^{\prime}$ randing di Tana Toraja.

1. Studi Pustaka

Studi pustaka bertujuan untuk memperoleh data dan informasi yang diperlukan dari berbagai sumber bacaan baik bersifat dokumen, buku-buku dan naskah tertulis lainnya yang relavan dengan permasalahan yang terkait dengan tari $P a$ 'randing. Adapun tujuan dari studi pustaka yaitu:

a. Untuk mengetahui apakah topik penelitian kita telah diteliti orang lain sebelumnya, sehingga penelitian kita tidak merupakan duplikasi. 
b. Untuk mengetahui hasil penelitian orang lain dalam sama sehingga kita dapat memanfaatkannya untuk penelitian kita.

c. Untuk memperoleh bahan yang mempertajam orientasi dan dasar teoritis kita tentang masalah penelitian kita.

d. Untuk memperoleh informasi tentang teknik-teknik penelitian yang telah diterapkan.

2. Observasi

Observasi adalah pengamatan meliputi kegiatan pemusatan perhatian terhadap sesuatu objek dengan menggunakan seluruh alat indera seperti penglihatan, pendengaran, penciuman, peraba, dan pengecap (Arikunto, 1998:146). Observasi sebagai alat pengumpulan data harus sistematis, artinya observasi serta pencatatannya dilakukan menurut prosedur dan aturan-aturan tertentu sehingga dapat diulangi kembali oleh peneliti lain.

Observasi dilakukan untuk mengetahui data tentang struktur gerak tari Pa'randing yang diteliti secara langsung dan sistematis mengenai segala bentuk fenomena-fenomena psikis dan penyelenggaranya pada pementasan tari $\mathrm{Pa}$ 'randing. Data-data yang didapat merupakan hasil pengamatan secara langsung dan hasilnya berupa catatan, foto, atau video. Ada beberapa tahap yang peneliti lakukan dalam melakukan observasi, yaitu pencatatan awal dengan jalan menuliskan kata kunci, dan pembuatan catatan lapangan secara lengkap. Melalui observasi ini dilakukan penelitian struktur gerak tari $P a$ 'randing yang dilihat dari geraknya yang tersusun dan tertata sehingga peneliti belajar dengan detail gerak tari $P a$ 'randing yang dilihat dari struktur geraknya tepatnya di Tana Toraja di Kecamatan Sangalla, Kabupaten Tana Toraja.

3. Wawancara

Wawancara adalah hubungan interaksi antara peneliti dengan narasumber yang bertujuan untuk mengkonstruksi mengenai orang, kejadian, kegiatan, organisasi, motivasi, tuntutan, kepedulian tentang situasi sosial. Adapun teknik wawancara yang dihubungkan adalah teknik wawancara terstruktur. Wawancara terstruktur adalah tanya jawab yang terarah untuk mengumpulkan data-data yang relevan, dalam wawancara ini karena pernyataan-pernyataan secara terstruktur dan sistematis, maka peneliti berdialog langsung dengan narasumber. Pertanyaan-pertanyaan yang diajukan beraturan, sehingga dalam memperoleh data di lapangan, peneliti dengan mudah memahami segala informasi yang diberikan. Dalam penelitian ini peneliti melakukan wawancara dengan guru dan penari yang ada di Tana Toraja yang bernama Andri sebagai informan yang dengan mengetahui tentang kesenian yang ada di Tana Toraja dan Yosep Rira Penari Pa'randing yang menghafal gerak tari $\mathrm{Pa}$ 'randing.

4. Dokumentasi

Teknik dokumentasi adalah salah satu metode pengumpulan data kualitatif melihat atau menganalisis dokumendokumen yang dibuat oleh subjek sendiri atau orang lain tentang objek yang diteliti dan merupakan salah satu cara yang dapat dilakukan peneliti untuk mendapatkan gambaran dari sudut pandang subjek melalui suatu media yang dipilih. Data dokumentasi memiliki keabsahan yang paling tinggi serta dapat 
dipertanggungjawabkan. Macam-macam dokumen yang digunakan adalah buku tentang tari Pa'randing yang berjudul etnografi penulis Halilintar Lathief dan Sumiani HL, buku seni Tradisional Sulawesi Selatan penulis Gunawan Monoharto. Foto-foto gerak tari Pa'randing, video tari Pa'randing saat pementasan yang di dokumentasikan sendiri saat observasi sebagai dokumen dalam penelitian. Berkenaan dengan penelitian ini dokumen tersebut diharapkan dapat memberikan informasi tentang struktur gerak tari Pa'randing. Dokumendokumen yang disertakan dalam penelitian ini antara lain foto, data media, dan pedoman wawancara tentang struktur gerak tari $\mathrm{Pa}$ 'randing yang terdapat pada lembar lampiran.

\section{HASIL}

Gambaran Umum tentang Tari Pa'randing dalam Upacara Rambu Solo'

Tari Pa'randing merupakan tarian perang atau tarian prajurit yang ditampilkan untuk memuji keberanian almarhum semasa hidupnya. Tari Pa'randing ditampilkan pada siang hari ketika Ma'pasonglo atau penerimaan rombongan tamu-tamu yang datang Tongkon (duduk bersama) di upacara Rambu Solo' di depan halaman tempat berlangsungnya upacara Rambu Solo' selama dua hari. Adapun karakter tari $\mathrm{Pa}$ 'randing yang tersusun dari ragam pertama ke ragam selajutnya geraknya tersusun dengan gerak yang dominan gerak kaki yang melompat-lompat beriringan dengan tangan kiri diayunkan dan tangan tangan memegang tombak dan perisai. Tempo gerak tari Pa'randing dengan tujuh hitungan yang geraknya sedang tidak terlalu cepat dan tidak terlalu lambat layaknya gerakan orang yang sedang berperang di medan pertempuran, gerakannya seperti orang yang saling menyerang dan menangkis lawan yang ada di depan. Pada tarian ini geraknya mengalir dan diulang-ulang sesuai tempat pertunjukan upacara Rambu Solo'. Dalam upacara Rambu Solo' tari Pa 'randing tidak dipentaskan selama upacara Rambu Solo' tetapi ada waktu dalam pelaksanaannya pada saat mengantar rombongan tamu yang datang dengan durasinya 02:00 menit sesuai lokasi halaman tempat pertunjukannya. Akan tetapi tarian ini tidak sembarang dipentaskan karena tidak semua orang yang meninggal akan mementaskan tari Pa'randing hanya keturunan bangsawan atau strata dalam masyarakat Toraja.

\section{Bentuk Tari Pa'randing di Tana Toraja}

Tari $P a$ 'randing adalah perang atau tarian prajurit yang ditampilkan untuk memuji keberanian almarhum semasa hidupnya. Ada 2 bentuk tari Pa'randing yang digunakan yaitu dalam Notasi laban dan tata hubungan ragam gerak. Notasi laban adalah seperangkat atau sistem lambang (tanda) yang menggambarkan bilangan, nada, atau ujaran dengan tanda huruf. Secara sepintas Notasi laban memang lebih sulit, tetapi sistem ini memiliki kelebihan yaitu mampu mencatat gerakan-gerakan yang lebih rumit sebagaimana gerak tari-tarian. Disamping itu, Notasi laban juga lebih luas dipakai di dunia tari seperti tari Pa'randing dengan mengunakan Notasi laban yang digambarkan melalui gerak ragam, dengan ini gerak tari Pa'randing dilihat dari kesatuan tata hubungan ragam gerak dengan bentuk gerak tari $\mathrm{Pa}$ 'randing ini akan menguraikan gerak dasar suatu tarian menjadi unsur gerak tari yang lebih kecil yaitu sikap dan gerak dari kepala, badan, tangan dan kaki dari bentuk gerak ini akan membentuk motif. Adapun hitungan tari $P a$ 'randing mempunyai hitungan ragam gerak yaitu ragam gerak Pamula yang bergerak hanya di tempat dengan hitungan 
1-7 hitungan dan dilakukan 3 kali. Ragam Tekka Tallu atau gerak tiga langkah hitungannya 1-7 hitungan yang dilakukan 3 kali dan ragam Ma 'putara atau ragam gerak memutar dengan hitungan 1-7 yang dilakukan hanya 1 kali dengan kembali ke ragam kedua yaitu ragam Tekka Tallu atau gerakan tiga langkah. Hitungan tari Pa'randing pada upacara Rambu Solo' tidak sesuai dengan hitungan yang sebenarnya para penari tari Pa'randing bergerak sesuai dengan keadaan tempat pertunjukan yang ada.

\section{Tata hubungan ragam gerak Tari Pa'randing \\ Ragam gerak Pamula}

Tata hubungan ragam gerak yang digunakan dalam tari $\mathrm{Pa}$ 'randing yaitu tata hubungan dilihat dari bentuk tata hubungan marfologis yang dalam tari Pa'randing saling keterkaitan yang terdiri dari tiga ragam yang setiap gerakannya menceritakan tentang peperangan yang berkembang dikalangan bangsawan. Dalam setiap ragam geraknya mempnyai pengambaran yang berbeda-beda seperti halnya ragam gerak Pamula dalam ragam ini penari bersiap-siap di tempat dimana dalam kalangan bangsawan mereka mengambarkan gerak ini sebagai semangat menjalani hidup yang kita miliki harus berjalan dan terarah untuk menatap masa depan dan menjalani hidup perlu memiliki persiapan dalam segala hal. Bentuk geraknya yaitu posisi penari menghadap ke depan dengan melompat-lompat di tempat seakan-akan menyerang lawan yang ada di depan, posisi badan penari pada ragam ini agak membukuk kedua lutut kanan dan kiri agak ditekuk, kepala tetap memandang ke depan, lengan tangan kanan sedikit dibengkokkan memegang perisai dan tombak sejajar dengan bahu kemudian tangan kiri lurus ke bawah. Penghubung dari ragam Pamula yaitu kaki kanan yang diangkat terlebih dahulu ke ragam selanjutnya yaitu ragam gerak Tekka Tallu. Hitungan gerakan ini tidak putus sampai 3 $\mathrm{x} 7$.

\section{Ragam gerak Tekka Tallu atau gerakan tiga langkah}

Kaki kanan yang terlebih yang terlebih dahulu melangkah. Pengambarang gerak ini dikalangan bangsawan bahwa kita hidup di dunia ini berdampingan dengan orang lain dan tidak hidup sendiri sehingga menghadapi tantangan harus percaya diri. Bentuk geraknya yaitu posisi badan tegak, kedua lutut tetap ditekuk untuk melangkah ke depan sebanyak 3 kali, kaki kanan melangkah terlebih dahulu diikuti kaki kiri, hitungan ke 4 kaki kiri mundur diikuti kaki kanan setelah 3 kali mundur kaki kanan di angkat satu kali untuk melangkah maju ke depan, lengan tangan kanan sedikit di bengkokkan memegang perisai dan tombak, tangan kiri diayun-ayunkan ke depan dan ke belakang beriringan dengan langkah kaki, kepala penari tetap menghadap ke depan. Hitungan ragam Tekka Tallu 3 x 7 hitungan. Penghubungan ragam gerak Tekka Tallu ke ragam gerak Ma'putara kaki kanan yang diangkat pada saat hitungan ke 7 dengan teriakan penari.

\section{Ragam gerak Ma'putara}

Ragam gerak ini lanjutan dari ragam gerak Tekka Tallu yang kaki kanan diangkat sebagai penghubung ragam gerak ini. Dikalangan bangsawan gerak ini menceritakan tentang melawan musuh dari peperangan yang tidak selamanya harus menang, ada saatnya kalah dari peperangan itu tetapi harus percaya diri bahwa semua akan kembali kepada Tuhan. Bentuk geraknya kedua kaki dirapatkan ditanah dan tetap ditempat melompat tiga kali lalu kaki kiri diangkat berputar kekanan 
setengah lingkarang lalu kembali ke ragam Tekka Tallu sambil tangan kiri diayunayunkan. Posisi badan tegak dengan kepala tetap menghadap kedepan, kaki kiri dan kanan melompat-lompat di tempat lalu posisi kedua kaki lututnya masih ditekuk dan kaki kiri diangkat untuk berputar ke kanan diikuti kaki kanan tetapi kaki kanan tidak diangkat hanya kaki kanan digeser ke sudut kanan lalu ke sudut kiri kemudian kaki kanan diangkat untuk kembali ke ragam Tekka Tallu. Hitungan ragam Ma'putara 1x7 hitungan, dengan penghubung gerak ini, pada saat kaki kanan diangkat pada hitungan ke 7. Berdasarkan penjelasan diatas dapat disimpulkan bahwa setiap ragam gerak tari Pa'randing dihubungkan dengan dimulai gerak kaki kanan yang diangkat.

\section{PEMBAHASAN}

Tari $P a$ 'randing dipentaskan dalam Upacara Rambu Solo'. Tari ini merupakan tarian perang atau tarian prajurit yang ditampilkan untuk memuji keberanian almarhum semasa hidupnya. Randing artinya memuji-muji, memuliakan dengan tarian, menghormati tamu dengan tarian, menyambut tamu dengan menari atau mempertunjukan tarian perang. $\mathrm{Pa}$ 'randing artinya orang (penari) yang gemar tarian perang Pa'randing. Pa'randing artinya saling memuji-muji. Jadi Pa'randing mempunyai pengertian nama sebuah tarian suku Toraja, orang yang pandai menari tari perang dan penari tarian Pa'randing pada pesta pemakaman jenasah golongan bangsawan dan orang yang berjasa yang meninggal dunia untuk memuliakan keberanian orang yang meninggal ketika masih hidup di Toraja dan tarian ini diperuntukkan hanya untuk laki-laki karena yang dulunya pergi berperang hanya lakilaki. Ada beberapa tingkatan sebagaimana stratifikasi dalam masyarakat Tana Toraja yaitu Tana' Bulaan adalah tingkatan bangsawan, Tana' Bassi tingkatan bangsawan menengah, Tana Karurung kasta masyarakat yang kebanyakan merdeka, Tana' Kua-kua tingkatan hamba sahaya kasta itu adalah orang-orang yang mengabdi kepada Tana' Bulaan dan Tana' Bassi.

Dalam upacara Rambu Solo' ada tiga jenis upacara Rambu Solo' yaitu upacara Rapasan Diongan, upacara Rapasan Sundun, dan upacara Sapu Randanan. upacara Rambu Solo' yang menampilkan tari Pa'randing yaitu upacara Rapasan Sundun yang diperuntukan bagi keturunan bangsawan dengan memotong kerbau 24 ekor atau lebih. Tari Pa'randing tidak dipentaskan selama upacara Rambu Solo' tetapi ada waktu dalam pelaksanaannya. Tari Pa'randing dipentaskan ketika rombongan masuk ke pondok, mereka berada di depan rombongan sambil menari. Dalam upacara Rambu Solo' tari Pa'randing untuk Ma'doloan (artinya mendahului untuk menunjukan jalan). Disinilah mereka menari untuk memuji keberanian almarhum yang telah meninggal. Seorang penari dalam tari Pa'randing ini harus memiliki kriteria. Kriteria-kriteria yang yang harus dimiliki oleh penari dalam tari $\mathrm{Pa}$ 'randing yaitu seorang tari Pa'randing khusus laki-laki yang terdiri 2-4 orang lebih, tergantung persiapan dari orang yang melaksanakan upacara Rambu Solo'. Jumlahnya boleh ganjil atau genap namun yang sering dipentaskan di Tana Toraja terdiri dari 3 atau 4 orang. Penari yang menarikan tari Pa'randing dalam upacara Rambu Solo' memiliki ciri khas jiwa pemberani, tangguh dan kuat. Penari tari Pa'randing yang menari di upacara Rambu Solo' harus keturunan bangsawan hal ini merupakan kriteria utama karena ketika menari harus terlihat bahwa yang meninggal memang memiliki jiwa yang pemberani. 
Adapun tiga ragam gerak tari Pa'randing yang bentuk ragam geraknya saling berhubungan yaitu:

1. Ragam gerak Pamula

Posisi awal penari bersiap di tempat, penari menghadap kedepan dengan melompat-lompat di tempat seakan-akan menyerang lawan yang ada di depan, posisi badan penari pada ragam ini agak membukuk kedua lutut kanan dan kiri agak ditekuk, kepala tetap memandang ke depan, lengan tangan kanan sedikit dibengkokkan memegang perisai dan tombak sejajar dengan bahu kemudian tangan kiri lurus ke bawah gerakan ini tidak putus sampai $3 \mathrm{x}$ 7 hitungan. Penghubung ragam gerak Tekka Tallu ke ragam gerak Ma'putara kaki kanan yang diangkat pada saat hitungan ke 7 dengan teriakan penari.

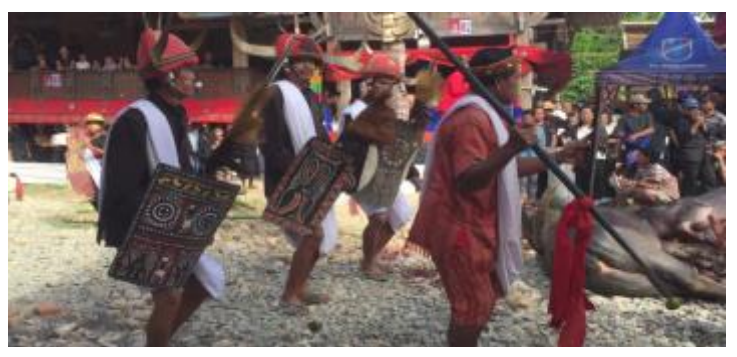

Gambar 1. Ragam gerak biasa atau Pamula (Dok. Feranita, Tahun 2018)

2. Ragam gerak Tekka Tallu atau gerak tiga langkah

Bentuk ragam gerak ini kaki kanan yang melangkah terlebih dahulu sebagai penghubung gerak Tekka Tallu penari melompat ke depan dengan kaki kanan melangkah diikuti kaki kiri sebanyak tiga langkah kedepan, lalu kaki kiri diangkat untuk gerakan mundur diikuti kaki kanan sebanyak tiga kali. Posisi badan tegak, kedua lutut tetap ditekuk untuk melangkah kedepan sebanyak 3 kali, kaki kanan melangkah terlebih dahulu diikuti kaki kiri, hitungan ke 4 kaki kiri mundur di ikuti kaki kanan setelah 3 kali mundur kaki kanan di angkat satu kali untuk melangkah maju ke depan, lengan tangan kanan sedikit di bengkokkan memegang perisai dan tombak, tangan kiri diayun-ayunkan ke depan dan ke belakang beriringan dengan langkah kaki, kepala penari tetap menghadap ke depan. Hitungan ragam Tekka Tallu 3 x 7 hitungan. Kaki kanan yang diangkat pada saat hitungan ke 7 dengan teriakan penari gerak ini penghubung untuk berpindah ragam gerak selanjutnya yaitu ragam gerak memutar. Gerakan ini menandakan berada dalam medan perang, melompat tiga kali ke depan berarti menendang musuh, dan mundur tiga kali berarti menahan musuh yang menyerang dan kembali gerakan awal.

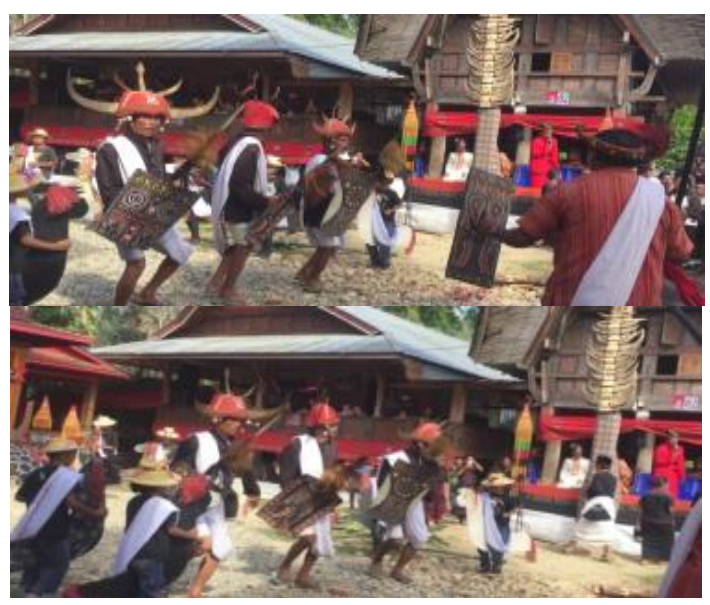

Gambar 2. Ragam Tekka Tallu atau gerakan tiga langkah

(Dok. Feranita, Tahun 2018)

3. Ragam gerak Ma'putara atau gerak memutar

Bentuk geraknya kedua kaki di rapatkan ditanah dan tetap di tempat melompat tiga kali lalu kaki kiri diangkat berputar kekanan setengah lingkarang lalu kembali ke ragam Tekka Tallu sambil tangan kiri diayun-ayunkan. Posisi badan tegak dengan kepala tetap menghadap 
kedepan, kaki kiri dan kanan melompatlompat di tempat lalu posisi kedua kaki lututnya masih ditekuk dan kaki kiri diangkat untuk berputar ke kanan diikuti kaki kanan tetapi kaki kanan tidak diangkat hanya kaki kanan digeser ke sudut kanan lalu ke sudut kiri kemudian kaki kanan diangkat untuk kembali ke ragam Tekka Tallu sekaligus penghubung dari gerak memutar ke ragam gerak Tekka Tallu. Hitungan ragam Ma'putara 1 x 7 hitungan, dengan penghubung gerak ini pada saat kaki kanan diangkat pada hitungan ke 7 .

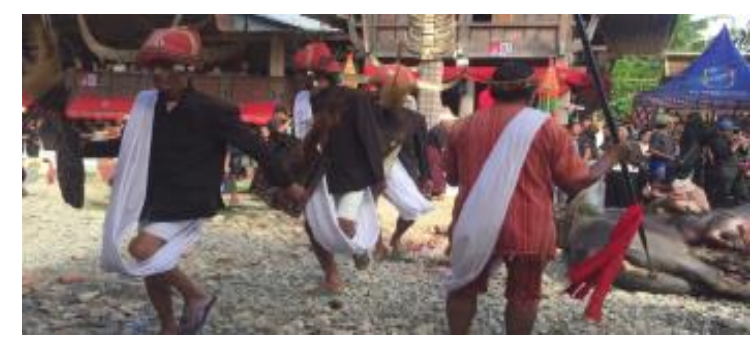

Gambar 3. Ragam gerak memutar

(Dok. Feranita, Tahun 2018)

Bentuk gerak tari $\mathrm{Pa}$ 'randing diatas saling berhubungan dalam bentuk Marfologis dilihat dari tari Pa'randing yang mempunyai tata hubungan ragam gerak yang saling berhubungan dan berkaitan dengan kaki kaki kanan yang diangkat sebagai penghubung dari ragam gerak Pamula ke ragam gerak Tekka tallu dan ragam gerak Ma'putara dan terdapat satu unsur gerak di ragam Pamula, dua unsur gerak di ragam Tekka Tallu dan dua juga unsur gerak di ragam Ma'putara.

\section{KESIMPULAN}

Berdasarkan hasil-hasil penelitian yang dikemukan pada Bab IV, maka dapat ditarik kesimpulan sebagai berikut : Ragam Tari Pa'randing terdiri dari 3 ragam diantaranya ragam gerak Pamula, ragam gerak Tekka Tallu, dan ragam gerak Ma'putara yang dilihat dari bentuk tangan, kaki, dan badan yang digambarkan dalam
Notasi laban. Semua ragam gerak dalam tari ini diuraiankan secara jelas dan setelah itu ditulis dalam notasi laban yang sesuai kaidah-kaidah penulisan yang telah ditetapkan. Sistem notasi laban ini bertujuan untuk melestarikan tari Pa'randing agar tidak punah apalagi sekarang ini sulit ditemukan lagi dan bahkan hampir tidak ada lagi generasi muda yang mendalaminya. Dengan sistem penulisan notasi laban dapat membantu generasi penerus dalam mempelajari tari Pa'randing dengan cara membaca notasi laban yang telah dituliskan kerena jika hanya menghandalkan ingatan untuk menghafal dan mengulangi kembali ingatan tentang tarian tersebut sangatlah rumit.

Tata hubungan tari Pa'randing termasuk tata hubungan bentuk Marfologis yang saling berhubungan antara ragam gerak. Misalnya ragam gerak Pamula bentuk geraknya dengan posisi penari menghadap ke depan dengan melompatlompat di tempat untuk ke ragam selanjutnya kaki kanan terlebih dahulu melangkah untuk memulai ragam gerak Tekka Tallu atau gerak tiga langkah bentuk ragam geraknya penari melompat ke depan dengan kaki kanan diikuti kaki kiri sebanyak tiga langkah ke depan, lalu kaki kiri diangkat untuk gerakan mundur diikuti kaki kanan sebanyak tiga kali dan kaki kanan diangkat diakhir ragam gerak Tekka Tallu dan ragam terakhir dari tari ini ragam gerak Ma'putara bentuk geraknya kedua kaki dirapatkan ditanah dan tetap di tempat melompat tiga kali hitungan lalu kaki kiri diangkat berputar ke kanan setengah lingkaran dan akhir hitingan kaki kanan diangkat sebagai penghubung untuk kembali ke ragam Tekka Tallu. Setiap ragam gerak pada tarian ini yang menghubungkan yaitu kaki kanan yang diangkat untuk berpindah ke ragam gerak selanjutnya. 
Jurnal Pakarena, Vol. 4 No. 2 Desember 2019, hlm 62-71

DAFTAR PUSTAKA

Bungariana, Sri. 2013. Studi Morfologi Tari Pattuddu Kumba Di Kecamatan Tinambung Kabupaten Polewali Mandar Dengan Sistem Notasi Laban. Skripsi. Makassar: Program Studi Seni Tari Universitas Negeri Makassar.

Dadang, Supardan. 2013. Pengantar Ilmu Sosial Sebuah Kajian Pendekatan Struktural. Jakarta: Bumi Aksara.

Duli, Akin dan Hasanuddin. 2003. Toraja Dulu dan Kini. Makassar: Pustaka Refleksi.

Hadi, Y. Sumandiyo. 2007. Kajian Tari Teks dan Konteks. Yogyakarta: Pustaka Book Publisner. 2012. Seni Pertunjukan dan Masyarakat Penonton. Yogyakarta: BP ISI Yogyakarta.

Bentuk-Teknik-Isi. Yogyakarta: Cipta Media.

Kristina, Dewi. 2015. Analisis Struktur Gerak Tari Trayutama. Skripsi. Semarang: Pendidikan Seni Tari Universitas Negeri Semarang.

Langan, Nolvianti Naomi. 2013. Makna Pesan Tari Pa'randing dalam Upacara Rambu Solo' di Tana Toraja. Skripsi. Makassar: Fakultas Ilmu Sosial dan Ilmu Politik Universitas Hasanuddin.

Lathief, Halilintar. 2016. Paduan Penulisan Proposal dan Laporan Skripsi. Yogyakarta-Makassar: Padat Daya.

Lathief, Halilintar dan Niniek Sumiani. 2014. Etnografi Tari Sulawesi. Yogyakarta: Padat Daya

Monoharto, Guenawan. dkk. 2004. Seni Tradisional Sulawesi Selatan. Makassar: Lamacca Press
Murgiyanto, Sal. 1983. Koreografi Pengetahuan Dasar Komposisi Tari. Jakarta: Departemen Pendidikan Dan Kebudayaan.

Jazuli, M. 2016. Peta Dunia Seni Tari. Slamet Riyadi: CV. Farishma Indonesia.

Panggara, Robi. 2015. Upacara Rambu Solo' di Tana Toraja Mamahami Kerukunan di Tengah Situasi Konflik.

Ritzer, George dan J. Goodman. 2008. Tori Sosiologi Modern. Jakarta: Kencana.

Royce, Anya Peterson. 2007. Antropologi Tari. Bandung: Sunan Ambu Press STSI.

Sari, Kartika Masria. 2013. Struktur Gerak Tari Tupai Jonjang di Kanagarian Lumpo Kecamatan IV Jurai Kabupaten Pesisir Selatan. Padang: Program Studi Pendidikan Sendratasik Universitas Negeri Padang.

Sebon, Elvin Tandi. 2009. Tari Pa'randing pada Upacara Rambu Solo' di Suaya Kecamatan Sanggalla' Kabupaten Tana Toraja. Skripsi. Makassar: Pendidikan Sendratasik Universitas Negeri Makassar.

Sumariyo dan Endo Suanda. 2006. Tari Tontonan. Jakarta: Pendidikan Seni Nusantara.

Tedi, Sutardi. 2007. Antropologi Mengungkap Keragaman Budaya. Bandung: Setia Purna.

Wahyudiyanto. 2008. Pengetahuan Tari. Surakarta: ISI Press 